Nigerian Journal of Technology (NIJOTECH)

Vol. 33 No. 4, October 2014, pp. 566 - 573

Copyright@ Faculty of Engineering,

University of Nigeria, Nsukka, ISSN: $1115-8443$

www.nijotech.com

http://dx.doi.org/10.4314/njt.v33i4.18

\title{
RAINFALL RUNOFF MODEL FOR CALABAR METROPOLIS USING MULTIPLE REGRESSION
}

\author{
R. E. E. Antigha ${ }^{1,}{ }^{*}$, A. J. Akor ${ }^{2}$, M. J. Ayotamuno 3 , I. Ologhodien ${ }^{4}$ and N. M. Ogarekpe ${ }^{5}$

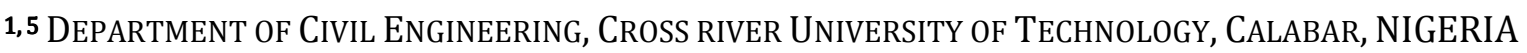 \\ 2,3 Dept of Agricultural and EnV. Eng., Rivers State Univ. of Science And TeCh., Port Harcourt, NiGERIA \\ 4 Department of Civil Engineering, Rivers State Univ. of Science And Technology, Port Harcourt, NiGERIA \\ E-mail addresses: ${ }^{1}$ revantiga68@gmail.com,2akor4@yahoo.com,3 mjayotamuno@hotmail.com, \\ 4itolima2000@yahoo.com,5nkpaogarekpe@yahoo.com,
}

\begin{abstract}
Mathematical analyses were used to develop model that predicts the influence of some hydraulic and hydrologic parameters on the perennial flooding of some parts of the Calabar Metropolis. The parameters were obtained from ten sampling locations all within Calabar metropolis. An empirical model was developed to predict discharge based on the independent variables of cross sectional area of drains, degree imperviousness, gradient, sum of channel length, and basin area. The model developed gave a good multiple regression coefficient of 0.982with a standard error of 0.709at a significance level of 0.10 . The $R^{2}$ value of the regression model shows that $96.4 \%$ of the total variation in the storm water discharge is accounted for by the five regressors. Incorrect sizing and spread of drains as well as the existing slopes employed in the generation of the drains' invert during construction have been seen as some of the key factors that foster flooding in the Metropolis. Designers are encouraged to employ the model developed for drains design and analysis for Calabar Metropolis.
\end{abstract}

Keywords: storm water, modeling, flooding, empirical, Calabar metropolis

\section{INTRODUCTION}

Man's need to protect himself and his possession from the threat of flood and erosion has remained one of the most important considerations in his struggle for survival. Historically, most cities of the developing world sprang up along the coastal regions as ports, often on the estuaries of rivers which served as commercial arteries. These coastal regions of the tropics in which Calabar Metropolis is one of such, have the highest average rainfall. However, due to the flat terrain and often alluvial soils, drainage is difficult. Large areas of impermeable surfaces and sparse vegetation in the urban centres, coupled with inadequate drainage facilities, results in the formation of excessive run-off within minutes of a storm event. This, of course often results to damage to lives and property.

The lack of drainage is especially serious where the ground is either steeply sloping or very flat. On very steep sites, as in parts of Luanda, Rio de Janeiro and Hong Kong, stormwater flows fast and violently, damaging buildings, eroding the land and sometimes causing landslides [1]. Also, very flat terrain leads to low flow velocities which often result in flooding.

In some parts of Calabar Metropolis, roads have been built by filling in channels. This has resulted in serious flooding. Where the natural drainage channels are not filled or obstructed by buildings, they often become blocked by domestic refuse. On the other hand, drainage improvements in one area are closely linked with drainage problems elsewhere. The current trend worldwide is towards urbanization. As a consequence, urban problems associated with the hydrologic aspects of water management should become increasingly more acute. Effective disposal of storm water has become very essential. Urban storm water management is no longer based on the interception, collection and disposal of storm water only, but also on the application of workable model approaches in storm drainage designs.

Sound storm water design practices help to maintain compatible drainage systems, minimize disturbance to 
existing drainage patterns, control flooding of property, structures, and roadways, and minimize environmental impacts of storm water runoff.

Urbanization tends to increase downstream peak flows, runoff volumes, and runoff velocities. These changes can cause the capacity of adequately designed downstream systems to be exceeded and disrupt natural waterways. The impacts of new urbanization are expected to be reduced through the use of structural and non-structural Best Management Practices (BMPs) that may include storm water detention.

In Calabar Metropolis, rapid and largely unplanned urban growth has, over the years, resulted in land use changes and modifications, which have resulted to changes in the hydrological fluxes in the urban watershed.

Over the past thirty-six years, the area of impervious surfaces in Calabar Metropolis has significantly increased. This has resulted from the several activities of man to foster urbanization and expedite development. In 1972 for instance, the city had an area of about $120.8 \mathrm{sqkm}$. At the end of 2006 however, the area had expanded to encompass not less than $480 \mathrm{sqkm}$, [2]. As urbanization continues, there is increased population density. This means that more areas have been devoted to housing and businesses. This in turn results in an increase in the area of ground covered with impervious surfaces. This should also mean that a good portion of the right-ofway of water, specifically overland flow, have been tampered with. Accordingly, as there are more impervious surfaces in the ever-spreading urban area, threat of flooding is bound to increase during any major storm event. This should be expected because water runs off quickly and there is an increase in peak discharge rates. This, of course overwhelms the various hydraulic structures and systems across the entire metropolitan area.

Parts of the southern part of Calabar Metropolis has been built through the common practices of land reclamation such as artificial landfill of depressions, back filling swamps, wetlands and floodplains. These practices, coupled with the inadequacy of drainage network, reduce the flood storage and overwhelm the carrying capacity of existing channelsthereby increasing urban storm throw-up during storm events in the metropolis.

In Calabar Metropolis, the dwellers are aware of the problems of urban storm water, but have no power over it. Some of them do not know what to do when caught up on foot or in their car by fierce and fast running waters on impervious roads or from storm water overflowing drainage systems whose storage capacities have been exceeded.

A storm water drainage system is a sub-system of the total urban water resource system. As such, storm water system planning and design for any new development must be compatible with watershed master plans and objectives, and must be coordinated with plans for land use, open space, transportation, and other community objectives. Watershed master plan must consistently address storm quantity and quality issues, as well as regional issues [3].

Storm water systems should be designed both to provide adequate surface drainage and to meet other important storm water management goals, such as protection of water quality, stream channels, habitat and groundwater. In addition, storm water management practices must strive to preserve and promote the general health, safety and welfare of the public. Storm water drainage is defined by watershed, not by administrative jurisdiction, and therefore requires co-operative efforts on a watershed basis to be implemented effectively. The aim of this study is to develop a rainfall runoff model for Calabar metropolis using the multiple regression approach. To this end, the specific objectives are as follows:

a. Identify the pertinent factors or variables of the drainage systems of Calabar Metropolis.

b. Develop a multiple regression model based on these factors.

\section{MATERIALS AND METHODS}

\subsection{Description of Area of Study}

Calabar Metropolis lies between latitudes 04 45’30" North and $05^{\circ} 08^{\prime} 30^{\prime \prime}$ North of the Equator and longitudes $8^{\circ} 11^{\prime} 21^{\prime \prime}$ and $8^{\circ} 30^{\prime} 00^{\prime \prime}$ East of the Meridian. The town is flanked on its eastern and western borders by two large perennial streams viz: the Great Kwa River and the Calabar River respectively. These are aside from the numerous ephemeral channels which receive water after storm events to drain the area of study.

The Calabar River is about 7.58 metres deep at its two major bands [4]. The city lies in a peninsular between the two rivers, $56 \mathrm{~km}$ up the Calabar River away from the sea. Calabar has been described as an inter-fluvial settlement [5].

The area is drained by the two main perennial channels, the Calabar and the Great KwaRivers. The 
rivers are fed by the numerous ephemeral and intermittent channels, gullies and rills which are inundated during the slightest storm events. Surface water is also carried by the sloping terrain, the roadside ditches and sandy soils which are pervious to water. The major ephemeral channel is the one truncating the city from the MCC/WAPI junction axis down to the Cross River University of Technology staff quarters on the south, and empting roughly and abruptly into the Great Kwa River.

Precipitation is characterized by a double maxima rainfall which starts from April and ends in October, reaching its peak in June and September. The average annual rainfall is about $1830 \mathrm{~mm}$ with some variations within the metropolis [6]. On the average over $80 \%$ of the total annual rainfall falls over a period of seven months (from April to October). June has an average rainfall of 530mm [7].

The metropolis, with a population of 202,585 in 1991, now has a population of over 450,000 [8]. This shows a growth or an increase in population of $52 \%$ or an average annual population increase of $3.1 \%$.

\subsection{Data Collection}

In order to achieve the general objectives of the study in, the following specific tasks were undertaken amongst others. (a). Collection of data such as storm and run-off events, land-use conditions, soil and vegetation details for Calabar Metropolis as well as a contour crenulations in order to observe the morphology of the drainage basin.

(b). Analyses of these collected data

(c). Selection of suitable storm events of the study catchments for model parameter calibration

Data for this work were acquired from two sources. These may be classed into primary and secondary source data. Primary source data were obtained from the reconnaissance survey, field experiments and analysis (rainfall, runoff, etc) whereas the secondary source data were obtained from review of existing literatures, e-library, e-books and other materials from the internet.

The two primary factors that contribute to the magnitude of a flood are rainfall and runoff response. Rainfall and runoff like most hydrologic events are governed by the laws of chance; hence, their predictions cannot be done in absolute terms [9]. The characteristics of rainfall that affect the magnitude of a flood amongst others are duration and intensity. These characteristics can be quantified for any given storm through the collection of rainfall data.

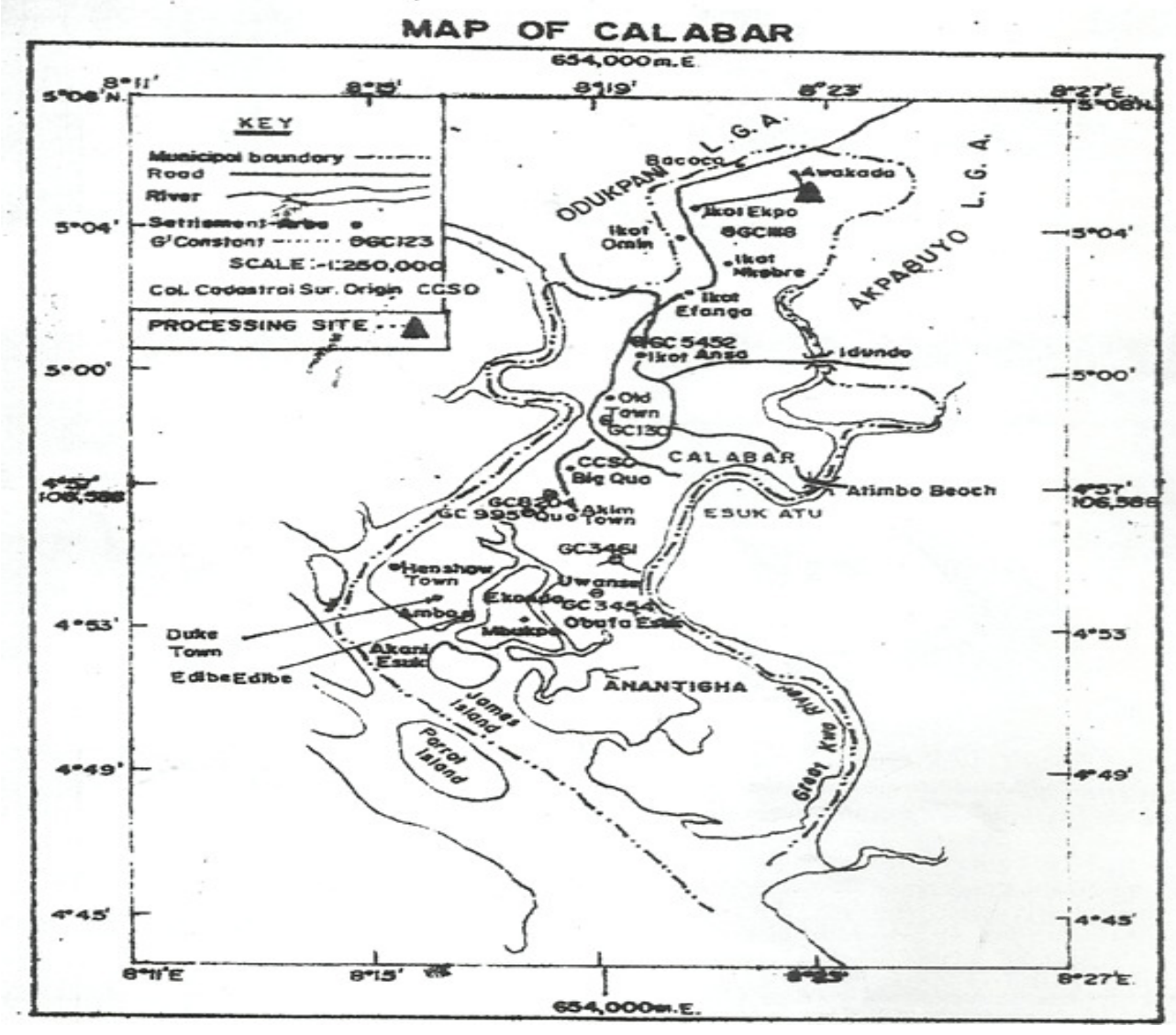

Figure 1: Outlay of Calabar Metropolis 


\subsection{Rainfall Data}

Two sets of rainfall events were obtained from NIMET [10] and used for the study. First, a thirty year data from 1978 to 2007 was obtained. This set of reading was done with the use of a tipping bucket rain guage with a 0.2 precision. Another set of readings was obtained for twenty-three months from January, 2008 to November, 2009. A self-recording guage was used for this set of readings. For this second set, a total number of three hundred and forty six (346) storm events were recorded. Five thousand, five hundred and eighty seven millimeters (5587 $\mathrm{mm}$ ) of rain was recorded for the period monitored. Total hours that rain fell were 1084.67hours. This gave an average rainfall of $242.9 \mathrm{~mm}$ per month of rain, and an average intensity of $5.15 \mathrm{~mm}$ per hour of rain.

\subsection{Runoff Data}

Flow measurements are critical to monitoring storm water best management practices (BMPs). Accurate flow measurements are necessary for accurate computing of samples used to characterize storm runoff and for the estimation of volumes. A total of ten (10) drainage outlets were selected as points for storm runoff readings. The choice of these ten locations was informed by their vulnerability to flooding, being major flood outlets in the catchment. Twenty (20) storm events were monitored at each recording point and 80 (eighty) runoff readings were taken from each reading point with the propeller- type current metre model A.OTT, Kempton type $\mathrm{F}_{4}$. The metre had a reading range of $\mathrm{n}<4.67, \mathrm{v}=0.0560 \mathrm{n}+$ $0.040 ; \mathrm{n} \geq 4.67, \mathrm{v}=0.0545 \mathrm{n}+0.047$ for propeller 1 and $\mathrm{n}<1.28, \mathrm{v}=0.0905 \mathrm{n}+0.040 ; \mathrm{n} \geq 1.2, \mathrm{v}=$ $0.1030 \mathrm{n}+0.024$ for propeller 2 where $\mathrm{v}$ is in $\mathrm{m} / \mathrm{s}$ and $\mathrm{n}$ is number of revolution. The readings were taken during the months selected as the wettest part of the year (May to October) and for storms with duration of not less than 120 minutes [10] [11].These gave a total of eight hundred (800) runoff readings. The readings were taken at the five minutes, ten minutes, fifteen minutes up to the one hundred and twenty minutes rainfall intervals. These were recorded as $I_{5} I_{10} I_{15}$ to $I_{120}$ respectively. These pattern and intervals conform to the hydrologic standards, [12] [13] [14].

\subsection{Guage data}

The Calabar River was gauged for thirty (30) days within the period considered as the wettest part of the year. The gauging station was set up approximately at the outlet where the main ephemeral channel of basin 4 empties storm water into the river. Sixteen (16) poles were used to set up the station. The poles were calibrated at ten (10) centimeter spacing and driven into place at the river bed. Poles were used to set up the station. An area from the continental shelf to the point designated as the shore line was covered. A leveling instrument was used to obtain the level after which, the survey compass was used to obtain the coordinates. Hourly readings of the rise and fall of the river were done. By improvising, a floater was incorporated to each of the sixteen metal poles rammed into place at the sea bed. Every rise or fall of the tide was reflected on the floater position which was observed by the natural optical method and recorded.

\subsection{Land Use Data}

Land use data were obtained from the most recent map (2011)of the study area obtained from the State Ministry of Lands and Survey. Areas occupied by buildings (built-up areas) were measured, as well as those areas harbouring farmlands, playground, undeveloped areas etc. The degree of imperviousness was obtained by determining their relative percentages of the built-up areas with reference to the total area as scaled.

\subsection{Gradient Data}

The gradient data for the sub- catchments were obtained through the profiling approach. A global positioning system (G.P.S) instrument was used. Mapping was done by marking off $25 \mathrm{~m}$ interval on ground. This was made to run to cover the whole length of the overland flow of the sub-drainage basins drained by the channels network. The inlet elevation was subtracted from the outlet elevation. The plot of the inlet and outlet elevations was obtained with reference to the overland flow length. The tangent of the angle so formed gave the value of the slope.

\subsection{Catchment Subdivision}

To account for areal variability of rainfall and losses, and to model different travel times of various parts of the catchment to the outlet, the catchment should be subdivided into a number of sub-catchments.

In general, three levels of subdivisions can be considered. They include: (a) coarse subdivision (neglecting all lateral drains and considering each catchment to contribute directly to the inlets of the 
main drain); (b) a medium subdivision (considering main drain and first order laterals) and (c) a fine subdivision (considering all drains) [15] [16]. The effect of the catchment subdivision is significant for the catchments, where routing effects dominate the rainfall - runoff process. For this research work, the medium subdivision was used.

\subsection{Model Development}

Hydrological modeling tools have been increasingly used worldwide in the management of water resources at watershed level [17]. Brezonik and Stadelmann [18] observed that empirical or statistical storm water models are usually based on regression analysis between water quantity and relevant explanatory variables. For this work, an empirical model was developed.

In terms of storm water modeling, an empirical approach would be a model that relates runoff quantity to a number of factors such as rainfall or other characteristics of the catchment. The predictive models were developed. The issue of discharge that often follows a storm event, which, depending on the intensity and duration of the storm, results to flooding, has been an issue of grave concern to engineering. This flooding has on many occasions, resulted in the loss of lives and property. Many attempts have been made by various governments, stake holders and professionals to curb this menace. Bridges, culverts, drainage channels and such other water conveying or diversion structures have been involved in this fight. To aid the model development, the assumption that, for a single storm event of average intensity, the length of the over land flow is, in a way proportional to the time of concentration which is taken as the time it will take for a storm runoff to travel from the inlet to the outlet of the sub basin or catchment was made.

In developing the model to attempt a solution to the perennial problem of flooding within the metropolis, if $\mathrm{Q}$ is the volume of discharge, and $\mathrm{R}$ is that for rain in time $t$, then,

$$
Q=K_{1} R(t)
$$

Where $K_{1}$ is a constant to be determined

The next factor which is a source of worry is the slope along the path the storm runoff travels across. This mathematically is called the gradient and it is a function of the angle of elevation.

If we let $y_{1}=$ elevation at the entry point $\mathrm{A}$, and $y_{2}=$ elevation at the outlet point, $\mathrm{B}$,
If $\mathrm{l}$ is the length of the overland flow between $\mathrm{A}$ and $\mathrm{B}$, $\mathrm{y}$ the horizontal distance between points $\mathrm{A}$ and $\mathrm{B}$, then the

$$
\begin{aligned}
& \text { Now } \operatorname{Sin} \theta \frac{y_{1}-y_{2}}{l} \\
& \theta=\sin ^{-1} \frac{y_{1}-y_{2}}{l}
\end{aligned}
$$$$
\text { Gradient AB } \frac{y_{1}-y_{2}}{x}=\tan \theta
$$

So,

$$
\text { gradient }=\tan \left[\sin ^{-1}\left(\frac{y_{1}-y_{2}}{l}\right)\right]
$$

The higher the slope, the lower the probability of flood and the lower the slope, the higher the probability of the area being flooded (i.e., gentler slopes do not encourage flooding and vice versa).

Therefore,

$$
\begin{aligned}
& \boldsymbol{Q} \propto \boldsymbol{s} \\
& \mathrm{Q}=\mathrm{k}_{2} \mathrm{~S}
\end{aligned}
$$

In (6) and (7), $K_{2}$ is a constant and $S=$ slope $=$ Gradient $A B=\tan \theta$

The next variable relevant to the model is the degree of imperviousness of the soil. Paved soils are known to allow water stand on them while undeveloped land areas, except compacted clays, allow infiltration. Free water only stands on undeveloped areas after soil water accretion has been satisfied. We say that

$$
\begin{aligned}
& \boldsymbol{Q} \propto \boldsymbol{p} \\
& \mathrm{Q}=\mathrm{k}_{3} \mathrm{p}
\end{aligned}
$$

Where $K_{3}$ is a constant, and $\mathrm{p}$ is the degree imperviousness. A very weak relationship exists between $S$ and $P$.

The next related variable which is rather man-made is the size of the drainage channel. Wide and deepened channels do not encourage overtopping, hence incidences of flooding are checked. The size of the drainage channel is represented by the cross sectional area, estimated geometrically as the function of the width and depth and spread (for trapezoidal cross sections)

$$
\begin{aligned}
& \text { Let } \mathrm{A}=\text { cross sectional area. Then, } \\
& Q \propto A s \\
& \mathrm{Q}=\mathrm{k}_{4} \mathrm{As}
\end{aligned}
$$

In (11), $K_{4}$ is a constant

Another factor that seems to have some influence on the quantity of discharge is the effort made by individual landlords who construct small holder drainage around and about their compounds. Where these are many, the quantity emptied into the main drainages is large and may lead to flooding. Where they are few, the rain may infiltrate into the soil or cause flood if the soil is waterlogged.

Artificial drainage density ADD is a derived variable that describes these phenomena: 


$$
A D D=\frac{\text { Area of basin, } A}{\text { Length of drainage, } L}
$$

So the expected relation is

$$
\begin{gathered}
\mathrm{Q} \propto \mathrm{ADD} \\
\mathrm{Q}=\mathrm{K}_{5}(\mathrm{~A})
\end{gathered}
$$

We can combine equations $1-13$ to obtain a single equation thus:

$$
\mathrm{Q}=\mathrm{K}_{0}+\mathrm{R}_{(\mathrm{t})} \mathrm{K}_{1}+\mathrm{K}_{2} \mathrm{~S}+\mathrm{K}_{3} \mathrm{P}+\mathrm{K}_{4} \mathrm{As}_{\mathrm{S}}+\mathrm{K}_{5} \mathrm{~A}
$$

This is identical to the multiple regression model given by,

$$
\mathrm{y}=\beta_{0}+\beta_{1} x_{1}+\beta_{2} x_{2}+\beta_{3} x_{3}+\beta_{4 X_{4}}+\beta_{5 X_{5}}+\varepsilon_{i j K}
$$

Where $\mathrm{y}=$ the dependent variable which is the discharge, measured as runoff, $\beta_{0}=$ regression constant, $\beta_{1}, \beta_{2} \beta_{3} \ldots . . \beta_{n}$ are the regression coefficients that measure the strength of the contribution of the associated variable in the prediction of the quantity of discharge ' $y$ '. The units of the five variables were decided as shown on Table 1 and 2:

Linear regression analysis was applied to test the validity of the model. The process involved estimating the model parameters $B_{0}, B_{1}$, $B_{2}, B_{3}, B_{4}$, and $B_{5}$ and the error called the standard error of estimates. There are two generally accepted methods: One is the least square method [19] [20]. Where the procedures are correctly and logically followed, the final results should be the same [21].

In practice however, the most popular and widely applied method is the least square method. This is the method applied here thus,

Let

$y_{0}=\beta_{0}+\beta_{1} x_{1}+\beta_{2} x_{2}+\beta_{3} x_{3}+\beta_{4 X_{4}}+\beta_{5 X_{5}}$

and

$y_{0}=\hat{\beta}_{0}+\hat{\beta}_{1} x_{1}+\hat{\beta}_{2} x_{2}+\hat{\beta}_{3} x_{3}+\hat{\beta}_{4} x_{4}+\hat{\beta}_{5} x_{5}$

where $\hat{\beta}_{i}$ are estimates of $\beta_{i}$

where $\sum_{x i}\left(y_{0}-y_{e}\right)^{2}$ is minimum

Equations (16) and (17) represent a plane in a five dimensional rectangular coordinate system and is generally referred to as a regression plane.

To find the least square regression plane, the values $\hat{\beta}_{\mathrm{i}},(\mathrm{i}=0,1,2 \ldots 5)$ was determined such that (18) is satisfied. In the case of $\mathrm{n}=2$ for example

$d^{2}=\left(y_{0}-y_{e}\right)^{2}$

Is obtained. Differentiating and equating to zero, a condition for the existence of a minimum yields $y_{0}=$ $\beta_{0}+\beta_{1} x_{1}+\beta_{2} x_{2}+$

for the system of normal equations

$\sum \boldsymbol{y}=\boldsymbol{n} \hat{\beta}_{0}+\hat{\beta}_{1} \sum x_{1}+\hat{\beta}_{2} \sum x_{2}$

$$
\begin{aligned}
& \sum x_{1} y=\hat{\beta}_{0} \sum x_{1}+\hat{\beta}_{1} \sum x_{1}^{2}+\hat{\beta}_{2} \sum x_{1} x_{2} \\
& \sum x_{2} y=\hat{\beta}_{0} \sum x_{2}+\hat{\beta}_{1} \sum x_{1} x^{2}+\hat{\beta}_{2} \sum x_{2}^{2}
\end{aligned}
$$

Solving this system using row reduction or Cramer's rule [22] yields the values of $\widehat{\beta}_{0}, \hat{\beta}_{1}$, and $\hat{\beta}_{2}$ that meet the least square criteria. This procedure can be generalized to any number of independent variables.

\section{RESULTS AND DISCUSSION}

Tables 1 - 2 show the values of the data acquired for use as variables from the different locations of the study. Applying regression analysis on the data obtained from Microsoft EXCEL, it was observed that a linear correlation existed between the data. The model developed gave a good multiple regression coefficient of 0.982 with a standard error of 0.709 at a significance level of 0.10 with an $\mathrm{R}^{2}$ value of 0.964 .

The equation below is obtained as an empirical regression model for the prediction of discharge of storm water for Calabar metropolis.

Table 1: Showing the mean velocity and discharge of the all the locations

\begin{tabular}{lllll}
\hline S/No. & Location & Mean Velocity $(\mathrm{m} / \mathrm{s})$ & Mean Discharge $\left(\mathrm{m}^{3} / \mathrm{s}\right)$ & Basin Area (ha) \\
\hline 1 - SB1 & Ediba One Area & 1.467 & 1.29 & 179.39 \\
2 - SB2 & Ediba Two Area & 1.755 & 3.73 & 274.75 \\
3 - SB3 & Ibom Layout Area & 0.886 & 0.56 & 189.29 \\
4-SB4 & Mayne Avenue Area & 0.880 & 0.55 & 280.15 \\
5-SB5 & Big Qua Area & 0.588 & 0.19 & 193.54 \\
6-SB6 & M.C.C Highway Area & 1.353 & 8.22 & 559.70 \\
7-SB7 & Yellow Duke/ Inyang Area & 0.934 & 0.52 & 220.98 \\
8-SB8 & Marina Area & 0.874 & 2.69 & 213.50 \\
9-SB9 & Marian Area & 0.751 & 0.17 & 301.37 \\
10-SB10 & Mary Slessor Area & 1.058 & 1.48 & 406.79 \\
\hline
\end{tabular}


Table 2: Showing the various locations and the Predictor Variables

\begin{tabular}{|c|c|c|c|c|c|c|c|c|}
\hline S/No. & Code & Area Name & $\begin{array}{c}\text { Measured } \\
\text { Discharge } \\
\left(\mathrm{m}^{3} / \mathrm{s}\right)\end{array}$ & $\begin{array}{c}\text { Cross } \\
\text { Sectional } \\
\text { Area of Area } \\
\left(\mathrm{m}^{2}\right)\end{array}$ & $\begin{array}{l}\text { Degree of } \\
\text { impervious } \\
\text { Area(\%) }\end{array}$ & $\begin{array}{l}\text { Gradient } \\
(\mathrm{m} / \mathrm{m})\end{array}$ & $\begin{array}{c}\text { Sum of } \\
\text { Channel } \\
\text { Length }(\mathrm{m})\end{array}$ & $\begin{array}{c}\text { Basin } \\
\text { Area (ha) }\end{array}$ \\
\hline & & & $\mathrm{y}$ & $\mathrm{X}_{1}$ & $\mathrm{X}_{2}$ & $\mathrm{X}_{3}$ & $\mathrm{X}_{4}$ & $\mathrm{X}_{5}$ \\
\hline 1 & SB1 & Ediba One Area & 1.291 & 0.88 & 71.01 & 4.6 & 2878 & 179.37 \\
\hline 2 & SB2 & Ediba two Area & 3.73 & 2.125 & 73.59 & 9.63 & 3005.24 & 274.75 \\
\hline 3 & SB3 & Ibom Layout Area & 0.558 & 0.63 & 76 & 16.53 & 2378.92 & 189.29 \\
\hline 4 & SB4 & $\begin{array}{l}\text { Mayne Avenue } \\
\text { Area }\end{array}$ & 0.554 & 0.63 & 75.4 & 6.21 & 1670.21 & 280.15 \\
\hline 5 & SB5 & Big Qua Area & 0.194 & 0.33 & 68.24 & 9.75 & 1379 & 193.54 \\
\hline 6 & SB6 & $\begin{array}{l}\text { M.C.C. Highway } \\
\text { Area }\end{array}$ & 8.221 & 6.075 & 73 & 7.07 & 4443.02 & 559.76 \\
\hline 7 & SB7 & $\begin{array}{l}\text { Yellow- } \\
\text { Duke/Inyang } \\
\text { Area }\end{array}$ & 0.52 & 0.556 & 74.9 & 1.697 & 3511.15 & 220.98 \\
\hline 8 & SB8 & Marina Road Area & 2.692 & 3.08 & 59.95 & 6.06 & 1895.36 & 213.5 \\
\hline 9 & SB9 & Marian Road Area & 0.165 & 0.22 & 72.3 & 8.26 & 2580.01 & 301.37 \\
\hline 10 & SB10 & Mary Slessor Area & 1.48 & 1.4 & 89.2 & 9.59 & 3178.07 & 406.79 \\
\hline
\end{tabular}

$\mathrm{y}=1.15 \mathrm{X}_{1}-0.016 \mathrm{X}_{2}+0.04 \mathrm{X}_{3}+0.0005 \mathrm{X}_{4}+0.001 \mathrm{X}_{5}-$ 0.591

In (16), $Y$ is the discharge $\left(\mathrm{m}^{3} / \mathrm{s}\right), \mathrm{X}_{1}$ is the cross sectional area $\left(\mathrm{m}^{2}\right), \mathrm{X}_{2}$ is the Degree of imperviousness (\%), $\mathrm{X}_{3}$ is the Gradient $(\mathrm{m} / \mathrm{m}), \mathrm{X}_{4}$ is the sum of channel length $(\mathrm{m})$ and $\mathrm{X}_{5}$ is the basin area (ha).

The regression analysis revealed that a positive relationship exist between discharge and cross sectional area $(\mathrm{p}<0.1)$. This implies that as the cross sectional area increases, the discharge also increases. On the other hand, the reverse is the case for degree of imperviousness, gradient, sum of channel length and basin area $(\mathrm{p}>0.1)$.

The summary of output of the regression analysis is shown below in Tables 3 and 4 .

Table 3: Regression Statistics

\begin{tabular}{lr}
\hline Variable & Value \\
\hline Multiple R & 0.9818688 \\
R Square & 0.9640663 \\
Adjusted R Square & 0.9191491 \\
Standard Error & 0.7086413 \\
Observations & 10 \\
\hline
\end{tabular}

Table 4: ANOVA

\begin{tabular}{lcrccc}
\hline & $d f$ & $S S$ & $M S$ & $F$ & Significance $F$ \\
\hline Regression & 5 & 53.89113435 & 10.77822687 & 21.46319453 & 0.005447529 \\
Residual & 4 & 2.008690152 & 0.502172538 & & \\
Total & 9 & 55.8998245 & & & \\
\hline
\end{tabular}

\begin{tabular}{lrrrrrrrr}
\hline & Coefficients & Standard Error & \multicolumn{1}{c}{ t Stat } & P-value & Lower 95\% & Upper 95\% & Lower 90.0\% & Upper 90.0\% \\
\hline Intercept & -0.5908 & 3.628477 & -0.16281 & 0.878561 & -10.665 & 9.483512 & -8.32611 & 7.144602 \\
X Variable 1 & 1.14709 & 0.34877 & 3.288948 & 0.030245 & 0.178745 & 2.115425 & 0.403562 & 1.890608 \\
X Variable 2 & -0.0161 & 0.067732 & -0.2372 & 0.824153 & -0.20412 & 0.171987 & -0.16046 & 0.128328 \\
X Variable 3 & 0.04022 & 0.070971 & 0.566752 & 0.601172 & -0.15682 & 0.237269 & -0.11108 & 0.191521 \\
X Variable 4 & 0.00049 & 0.000451 & 1.075812 & 0.342573 & -0.00077 & 0.001738 & -0.00048 & 0.001447 \\
X Variable 5 & 0.00091 & 0.004862 & 0.187617 & 0.86031 & -0.01259 & 0.014411 & -0.00945 & 0.011277 \\
\hline
\end{tabular}




\subsection{CONCLUSION}

Studies on the perennial flooding of some parts of the Calabar Metropolis was undertaken. An empirical model was developed to predict discharge based on the independent variables of cross sectional area of drains, degree imperviousness, gradient, sum of channel length, and basin area.96.41\% of the total variation in the storm water discharge is accounted for by the five regressors. The empirical regression analysis of the data obtained revealed that the equation obtained above is a prediction regression model for the determination of discharge in Calabar metropolis. The model when applied will enhance the prediction of the adequacy of the density of the drains to accommodate the storm runoff generated in the Metropolis vis-a-vis considering the high population growth rate of our city centers and their corresponding urbanization. Legislation against construction along the right-of-way of storm runoff and the provision of adequate drainage outlets is recommended in curbing the menace of flooding within the Metropolis. In addition, the use of empirical approach instead of the rule-of-thumb is also recommended in the design of the storm drainage systems in the metropolis.

\section{REFERENCES}

[1] WHO, Surface water drainage for low-income communities, Geneva, 1991.

[2] Calabar Master Plan, 1972.

[3] Drainage Manual, Drainage criteria manual. Rogers, Arkansas, 2012.

[4] Tesko-kutz, A Survey \& Development Plan for Calabar: The Government of South-Eastern State of Nigeria, Calabar. 1973.

[5] Ugbong, I.A. An analysis of runoff flow, channel characteristics, flood and erosion menace in the Calabar drainage basin. An MSc Research, Dept. of Geography and Regional Planning, University of Calabar, 2000.

[6] Nigerian Airports Authority, Weather Report, 1995.

[7] Antigha, R.E.E, Analytical Modelling of RainfallRunoff for Calabar Metropolis, Cross River State, Nigeria: PhD Dissertation (in press), Dept. of Agric\& Environmental Engineering, Rivers State University of Science \& Technology, Port Harcourt, Nigeria, 2014.

[8] Cross River State Ministry of Land and Housing, 2008.
[9] Dike, B. U. and Nwanchukwu, B. A., Analysis of Nigeria hydrometeorological data. Nigerian Journal of Technology, Vol. 22, No. 1, 2003. pp. 29-38.

[10] Nigerian Meteorological Agency, 2010.

[11] Darayatne, S. L (2001). Modeling of Urban Storm water Drainage Systems using ILSAX. PhD Thesis, Victoria University, Australia.

[12] State of New Jersey Urban Storm Drainage Design Manual, 2007.

[13] Storm Water Drainage Criteria Manual, Urban Drainage and Flood Control District, City of New Jersey, Vol. 1, R051-56, 2007-01.

[14] Dendrou, S.A and Talavage, J.J, Optimal Planning for Urban Storm Drainage Systems. Jour. of the Water Resources Planning and Management Division, Vol.104,No.1, Nov 1978, pp.17-33.

[15] Johansen, R.C; Imhoff,J.C; Kittle, J.L.Jr.andDonigian, A.S. Jr. Hydrological Simulation Program FORTRAN (HSPF): User's Manual for Release 8.0, Office of Research and Development, Environmental Research Laboratory, Athens, G.A. Vol. 1\&2, 1989.

[16] Maheepala, U.K, Dayaratne, S.T. and Perera, B.J.C., "Diagnostic Checking and Analysis of Hydrologic Data of Urban Stormwater Drainage Systems", 25th Hydrology and Water Resources Symposium and 2nd International Conference on Water Resources and Environment Research, Queensland, Australia, 6-8 July 1999, pp 813-818.

[17] Adeogun, A.G; Sule, B.F; Salami, A.W and Okeola, O.G. Gas-Based Hydrological Modelling Using SWAT: Case Study Of Upstream watershed of Jebba reserviour in Nigeria. Nigerian Journal of Technology, Vol. 33, No. 3, 2014. pp. 351-358.

[18] Brezonik, P. L., Stadelmann, T. H. Analysis and predictive models of stormwater runoff volumes, loads, and pollutant concentrations from watersheds in the Twin Cities metropolitan area, Minnesota, USA. Water Research 36:2002, pp. 17431757

[19] Draper, N.R. \& Smith, Harry. Applied Regression Analysis, $2^{\text {nd }}$ Edition, California: John Wiley, California, 1981.

[20] Zar, J.H. Biostatistical Analysis, $4^{\text {th }}$ Edition, Michigan Prentice Hall PTR, 1999.

[21] Kerlinger, F. Foundation of Behavioural Research, $3^{\text {rd }}$ Edition. New York: Holt, Rinehart and Winston, 1986

[22] Kreyzic, E. Advanced Engineering Mathematics, Ohio: John Wiley \& Co., 1994. 